\title{
Description of Smoking Behavior in Adolescents During The Covid-Pandemic
}

\author{
${ }^{1}$ Dwi Ramadini, ${ }^{2}$ Irja Sriani Masitha, ${ }^{3}$ M. Fanny Afriansyah, ${ }^{4}$ M. Herlangga Putra \\ Faculty of Public Health, Muhammadiyah University of Jakarta \\ K.H. Ahmad Dahlan, Cireundeu, Ciputat, South Jakarta, 15419 \\ E-mail: anyanymasitha@gmail.com
}

\begin{abstract}
The behaviors that young people exhibit in the COVID-19 era are the strong behaviors in which the four information ants interviewed have different behaviors in the experience, expectations, the number of cigarettes, and the type of cigarettes consumed. Smoking behavior is one form of behavior encountered in people's lives and can be found in various places such as in crowded places, streets, city buses, hospitals, schools, and so on. A smoking habit can cause damage to the lungs and airways that will cause diseases of the respiratory system, such as chronic bronchitis, emphysema, even lung cancer. Schools and People need to be involved in efforts to prevent and intervene in adolescent smoking behavior more intensively.
\end{abstract}

Keywords: Sociologic Behavior, Teens, Covid-19 Pandemic 


\section{INTRODUCTION}

Smoking is one of the factors that affect a person's lung function. Smoking can lead to changes in the structure and function of the respiratory tract and lung tissue. In the large airways, mucosal cells are enlarged (hypertrophy) and the mucous glands multiply. In the small respiratory tract, mild inflammation to narrowing due to increased mucus buildup cells. In pulmonary tissue, there is an increase in the number of inflammatory cells and damage to alveoli. Due to changes in the anatomy of the airway, in smokers, there will be lung function and all kinds of clinical changes. This is the main basis for chronic pulmonary obstruction disease (Ministry of Health RI 2003)

Cigarettes are one of the leading causes of death in the world and are legal products that kill a third to half of their users on average die faster. According to the World Health Organization (WHO) in 2008, an estimated 5.4 million people die annually from cigarettes. (dakwatuna.com, 2008).

The problem of cigarettes is a public health problem experienced by the world's population today. According to who, about 1.3 billion people worldwide are smokers (Tarupay, 2014). WHO data (2004) states that cases of death from cigarettes annually reach 5 million people, $70 \%$ occur in developing countries, including in the Asian region, such as Thailand and Indonesia. Who estimates that by 2020 tobacco-related diseases will become the world's leading health problem causing 8.4 million deaths annually and half occurring in Asia (Ministry of Health, 2006). In addition, WHO has also warned that in the decade 2020-2030 tobacco will kill 10 million people per year, $70 \%$ of which occurs in developing countries (WHO, 2007).

Smoking habits will accelerate the decline of par. In people with normal lung function and nonsmoking decreased FEVI $20 \mathrm{ml}$ per year, while in people who smoke (smokers) will experience FEVI more than 50ml per year. Pulmonary dungs examination is done with a device called spirometry.

Based on Basic Health Research (Riskesdas) data, in 2010 the prevalence of people aged 15 years and above who smoked daily was $28.2 \%$. The prevalence of smokers is more in males, marital status, living in rural areas, with low education that is not finished and finished elementary school (SD). According to the work, the prevalence of smokers is more common in farmers/fishermen/laborers followed by the self-employed and the unemployed and tends to increase with increasing economic status.

Smoking can also result in a variety of other diseases, such ascardiocardicular disease (heart and blood loss) or cancer in other organs outside the system. These diseases can weaken the system, making it difficult for the body to fight the incoming Coronavirus. (Salsabil, Santoso and Zainudiin, 2020)

As a result, the virus becomes more developed and causes more heavy damage to the channel as well as the lungs. If smokers had experienced the decline of the function of the parliament, a Coronavirus infection would certainly make this condition so bad. This is what causes it to be more 
robust in the experience of the application and death due to the Coronavirus. The system of spreading the virus through cigarettes is also very easy because people don't know if the cigarette is sterile or not and directly inserted into the mouth of the mouth is precisely the rest of what the cigarette is exposed to or not, and if the cigarettes are exposed, then the virus will be inhaled and directly inserted into one's body, based on this is why smokers can be more readily affected by the coronavirus (Komasari, 2000). (Salsabil, Santoso and Zainudiin, 2020).

\section{METHODS}

His research is a type of investigative quality by conducting interviews using questionnaires that raise 10 questions about the behavior of teenagers in their lifetime to 4 teenage informants directly or online.

\section{RESULTS AND DISCUSSIONS}

Table 1. Results of this Research

\begin{tabular}{|c|c|c|c|c|c|}
\hline Topic & Meaning Unit & Code & $\begin{array}{c}\text { Sub } \\
\text { Category }\end{array}$ & Category & Theme \\
\hline $\begin{array}{l}\text { When did the } \\
\text { brothers smoke } \\
\text { first? }\end{array}$ & $\begin{array}{l}\text { 1. } 2 \text { SMA } \\
\text { 2. } 3 \text { SMA } \\
\text { 3. } 3 \text { SMA } \\
\text { 4. } 2 \text { SMA }\end{array}$ & $\begin{array}{ll}\text { 1. } & \text { Teen } \\
\text { 2. } & \text { Mature } \\
& \text { Mature } \\
\text { 3. } & \text { Teen }\end{array}$ & $\begin{array}{l}\text { Schoolb } \\
\text { oys }\end{array}$ & $\begin{array}{l}\text { Smokers } \\
\text { dominated by } \\
\text { schoolchildren }\end{array}$ & $\begin{array}{l}\text { response of } \\
\text { teenagers at } \\
\text { the } \\
\text { beginning of } \\
\text { smoking }\end{array}$ \\
\hline $\begin{array}{l}\text { How did you first } \\
\text { taste the } \\
\text { cigarette? }\end{array}$ & $\begin{array}{l}\text { 1. Initially try } \\
\text { addiction } \\
\text { 2. Feeling } \\
\text { Calm }\end{array}$ & $\begin{array}{l}\text { 1. Dabble in } \\
\text { continuing the } \\
\text { beauty }\end{array}$ & $\begin{array}{l}\text { Sense of } \\
\text { dexterity }\end{array}$ & $\begin{array}{l}\text { What he felt the } \\
\text { first time he was } \\
\text { smoking }\end{array}$ & $\begin{array}{l}\text { response of } \\
\text { teenagers at } \\
\text { the } \\
\text { beginning of } \\
\text { smoking }\end{array}$ \\
\hline $\begin{array}{lr}\text { Do your parents } \\
\text { know how young } \\
\text { people } \\
\text { squatting? }\end{array}$ & $\begin{array}{l}\text { 1. Don't know } \\
\text { until now } \\
\text { 2. It's always } \\
\text { been in } \\
\text { anger when } \\
\text { you know } \\
\text { it's smoking. } \\
\text { 3. I didn't } \\
\text { know until } \\
\text { now that I } \\
\text { was } \\
\text { smoking. } \\
\end{array}$ & $\begin{array}{lll}\text { 2. } & \text { Do know } & \\
\text { 3. } & \text { Already } & \\
\text { 4. } & \text { Know } & \\
\text { 5. } & \text { Not } & \text { yet } \\
& \text { known } & \end{array}$ & $\begin{array}{l}\text { Know it and } \\
\text { there's } \\
\text { nothing to } \\
\text { know }\end{array}$ & $\begin{array}{l}\text { Parents' } \\
\text { ignorance of } \\
\text { smoking/not }\end{array}$ & $\begin{array}{l}\text { His response } \\
\text { was youthful } \\
\text { at the start of } \\
\text { smoking }\end{array}$ \\
\hline $\begin{array}{l}\text { There's a reason } \\
\text { why the air of } \\
\text { smoking }\end{array}$ & 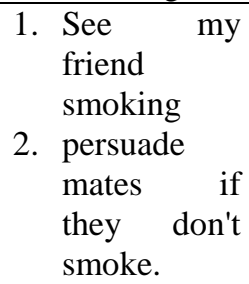 & $\begin{array}{l}\text { 1. Impersonate a } \\
\text { man } \\
\text { 2. Persuaded by } \\
\text { a man } \\
\text { - }\end{array}$ & $\begin{array}{l}\text { Influence of } \\
\text { a friend }\end{array}$ & Why smoking & $\begin{array}{l}\text { His response } \\
\text { was youthful } \\
\text { at the start of } \\
\text { smoking }\end{array}$ \\
\hline $\begin{array}{l}\text { And try telling me } \\
\text { how the microbes } \\
\text { got to smoking? }\end{array}$ & $\begin{array}{l}\text { 1. Initially just } \\
\text { try } \\
\text { 2. Prestige sees } \\
\text { friends } \\
\text { smoking }\end{array}$ & $\begin{array}{l}\text { 1. Curious } \\
\text { 2. prestige } \\
\text { 3. Impersonate a } \\
\text { man }\end{array}$ & $\begin{array}{l}\text { Influence of } \\
\text { a friend }\end{array}$ & $\begin{array}{l}\text { Causes } \\
\text { smoking }\end{array}$ & $\begin{array}{l}\text { His response } \\
\text { was youthful } \\
\text { at the start of } \\
\text { smoking }\end{array}$ \\
\hline
\end{tabular}




\begin{tabular}{|c|c|c|c|c|c|}
\hline Topic & Meaning Unit & Code & $\begin{array}{c}\text { Sub } \\
\text { Category }\end{array}$ & Category & Theme \\
\hline & & $\begin{array}{l}\text { 4. Influence of a } \\
\text { friend }\end{array}$ & & & \\
\hline $\begin{array}{l}\text { At what age are } \\
\text { you first } \\
\text { smoking? }\end{array}$ & $\begin{array}{l}\text { 1. } 17 \text { year } \\
\text { 2. } 18 \text { year } \\
\text { 3. } 18 \text { year } \\
\text { 4. } 17 \text { year }\end{array}$ & $\begin{array}{ll}\text { 1. } & \text { Adolescent } \\
\text { 2. } & \text { Adul } \\
\text { 3. } & \text { Adult } \\
\text { 4. } & \text { Adolescent }\end{array}$ & $\begin{array}{l}\text { Dominated } \\
\text { by high } \\
\text { school youth }\end{array}$ & $\begin{array}{ll}\text { Age } & \text { when } \\
\text { smoking } & \end{array}$ & $\begin{array}{l}\text { His response } \\
\text { was youthful } \\
\text { at the start of } \\
\text { smoking }\end{array}$ \\
\hline $\begin{array}{l}\text { At what age are } \\
\text { you first } \\
\text { smoking? }\end{array}$ & $\begin{array}{l}\text { 1. Half edition } \\
\text { 2. } 2 \text { trunk day } \\
\text { 3. } 1 \text { wrap } \\
\text { 4. } 3-8 \text { bars day }\end{array}$ & $\begin{array}{l}\text { 1. } 8 \text { trunk } \\
\text { 2. } 2 \text { trunk } \\
\text { 3. } 16 \text { trunk } \\
\text { 4. } 8 \text { trunk }\end{array}$ & $\begin{array}{l}\text { Number of } \\
\text { cigarettes } \\
\text { consumed }\end{array}$ & $\begin{array}{l}\text { Number of } \\
\text { cigarettes } \\
\text { consumed daily }\end{array}$ & $\begin{array}{l}\text { His response } \\
\text { was youthful } \\
\text { at the start of } \\
\text { smoking }\end{array}$ \\
\hline $\begin{array}{l}\text { Is there a feeling } \\
\text { of wanting to stop } \\
\text { smoking? }\end{array}$ & $\begin{array}{l}\text { 1. There's a } \\
\text { sense of } \\
\text { wanting to } \\
\text { stop } \\
\text { 2. There but } \\
\text { it's hard to } \\
\text { stop } \\
\text { 3. Not only } \\
\text { lack of } \\
\text { confidence }\end{array}$ & $\begin{array}{ll}\text { 1. } & \text { There Are } \\
\text { 2. No } \\
\text { 3. Active } \\
\text { Smokers }\end{array}$ & $\begin{array}{l}\text { Some have } \\
\text { smoking and } \\
\text { some don't } \\
\text { have } \\
\text { smoking. }\end{array}$ & $\begin{array}{l}\text { The desire to } \\
\text { stop smoking }\end{array}$ & $\begin{array}{l}\text { His response } \\
\text { was youthful } \\
\text { at the start of } \\
\text { smoking }\end{array}$ \\
\hline $\begin{array}{l}\begin{array}{l}\text { Please tell me } \\
\text { how long } \\
\text { smoke? }\end{array} \\
\end{array}$ & $\begin{array}{l}\text { 1. I've been } \\
\text { smoking for } \\
\text { at least } 1 \\
\text { month }\end{array}$ & $\begin{array}{l}\text { 1. } 1 \text { moon } \\
\text { 2. } 4 \text { moon } \\
\text { 3. } 3 \text { moon } \\
\text { 4. } 5 \text { moon }\end{array}$ & $\begin{array}{l}\text { There are } \\
\text { starters and } \\
\text { some who } \\
\text { have become } \\
\text { active } \\
\text { smokers }\end{array}$ & $\begin{array}{l}\text { Duration } \\
\text { smoking }\end{array}$ & $\begin{array}{l}\text { His response } \\
\text { was youthful } \\
\text { at the start of } \\
\text { smoking }\end{array}$ \\
\hline $\begin{array}{l}\text { What kind of } \\
\text { cigarettes } \\
\text { smoked? }\end{array}$ & $\begin{array}{l}\text { 1. GudangGara } \\
\text { m Filter } \\
\text { 2. GudangGara } \\
\text { m Filter } \\
\text { 3. Sampurna } \\
\text { Mild } \\
\text { 4. Magnum } \\
\text { Blue }\end{array}$ & 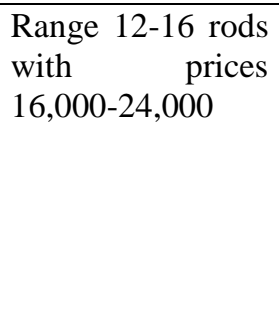 & $\begin{array}{l}\text { Relatively } \\
\text { expensive } \\
\text { for learners }\end{array}$ & $\begin{array}{l}\text { Type } \\
\text { cigarettes }\end{array}$ & $\begin{array}{l}\text { His response } \\
\text { was youthful } \\
\text { at the start of } \\
\text { smoking }\end{array}$ \\
\hline
\end{tabular}

The discussion will explain how the outline of interview results obtained from adolescents on smoking behavior in adolescents during the COVID-19 pandemic.

The behavior shown by adolescents during the COVID pandemic was smoking behavior where the four informants interviewed had differences in good behavior in experience, expectations, many cigarettes, and types of cigarettes consumed.

According to Adliyani (2015), behavior is a reaction through deeds consisting of thinking, moving, learning, having sex, and so on. Behavior can also be said to be a manifestation of interaction 
with the environment through deeds that can be seen or can not be seen (Nurlaela, 2014). Thus, it can be seen that this behavior is the result of a reaction in the form of actions that are influenced by external factors.

Sari (2019) suggests that adolescents become individuals who are vulnerable to outside influences, one of which is smoking behavior. Teenagers become very easily affected because of their highly curious nature to do things that have never been done before. Looking at this fact, it is clear that the results indicate a strong association between behavior and cigarette consumption obtained from interviews.

Questions were raised about how they could have smoking behavior. The majority of respondents also admitted that they started smoking because of invitations from peers or social friends who were in school. This evidence suggests that outside influences such as friends easily influence adolescents to smoke. Some informants said that their friend invited them to smoke for several reasons. The rest say that it feels bad if you do not participate in smokers

Other questions were also raised about whether their parents knew about the smoking or smoking behavior. the majority of respondents said that their parents did not know about their smoking behavior. the rest said that their parents were aware of the behavior but ignored it despite being scolded.

In addition, teenagers are told about how much cigarettes they consume. The majority of teenagers say they can spend roughly a pack of cigarettes. The rest claim that they can spend only 2 cigarettes a day. this indicates that the number of cigarettes consumed may vary.

Questions were also raised about whether there was a desire for teenagers to quit smoking. The majority of respondents said they wanted to quit smoking. The rest say that do not want to stop smoking. From this recognition, it appears that the influence of cigarettes on the rest is very bad because it binds or can not release the habit. Surely this behavior is still there hope for teenagers not to engage in smoking behavior.

Other questions were also raised about why they had not been able to quit smoking. The majority said that they did not want to quit smoking because they were addicted to cigarettes. Even other questions show that teenagers who do not smoke can cause quite serious effects such as not being able to focus or feel dizzy. This suggests that adolescents are already showing dependence on cigarettes.

\section{CONCLUSIONS AND SUGGESTIONS}

Cigarettes are toxic objects that give a relaxing effect. However, behind it contained a very great danger for people who smoke and people who are around smokers who are not smokers. Cigarettes have a middle-aged ingredient. The general public also knows that cigarettes can harm health. 
Smoking behavior is one form of behavior encountered in people's lives and can be found in various places such as in crowded places, streets, city buses, hospitals, schools, and so on. Viewed from various points of view is very detrimental, both for yourself and the people around him. The result of smoking behavior in terms of health is the presence of cigarette-containing chemicals such as nicotine, carbon monoxide tar, lead, ammonia, hydrogen cyanide ( $\mathrm{HCN})$, nitrous oxide, phenols, and hydrogen sulfide.

A smoking habit can cause damage to the lungs and airways that will cause diseases of the respiratory system, such as chronic bronchitis, emphysema, even lung cancer. These conditions can decrease lung function to extract oxygen from the air. In the event of coronavirus infection, lung function will decrease, so it is very risky to experience shortness of breath that can be fatal, not only cause respiratory problems.

Schools need to be involved in preventing and intervening in adolescent smoking behavior more intensively. Parents who want their children not to smoke need to be wary of the peer group of children, family members are not advised to smoke or do not give positive confirmation when teenagers smoke and the government makes regulations that limit the distribution of cigarettes and the age of consumers who can buy as well as cigarette advertisements circulating in the community to minimize the chances of children and adolescents to become consumers of cigarettes.

\section{REFERENCES}

Adliyani. 2015. PengaruhPerilakuIndividuterhadapHidupSehat. Majority, 4

DepartemenKesehatanRepublik Indonesia. Risetkesehatandasar (Riskesdas) 2007 nasional. Jakarta: DepartemenKesehatanRepublik Indonesia; 2008.

Komalasari, D. \& Helmi, AF. (2000). Faktor-FaktorPenyebabPerilakuMerokokPadaRemaja. JurnalPsikologiUniversitasGadjahMada, 2. Yogyakarta: UniversitasGadjahMada Press.

Martini, Sih. 2014. MaknaMerokokpadaRemajaPutriPerokok(Smoking Meaning In Young Woman Smokers). JurnalPsikologiPendidikandanPerkembangan Volume 3, No.2

Nurlaela. 2014. PERANAN LINGKUNGAN SEBAGAI SUMBER PEMBELAJARAN GEOGRAFI DALAM MENUMBUHKAN SIKAP DAN PERILAKU KERUANGAN PESERTA DIDIK. JurnalGea Volume, 14

Sari. 2019. PerilakuMerokok di KalanganSiswaSekolahMenengahAtas di Kota Padang. JurnalIlmiahKesehatanMasyarakat, 11.

World Health Organisation. 2004. Gender in Lung Cancer and Smoking Research. [Online]. www.who.int/entity/gender/documents/tobacco/9241592524/en/. Diakses November 2015

Abdurrachman, M. R. (2020) 'Analisis Perilaku Kesehatan Tentang COVID-19 Terhadap Minat Berhenti Merokok pada Perokok Aktif di Kota Palembang', p. 77.

Darajat, Z. (1977) Membina Nilai-Nilai Moral di Indonesia. Jakarta: Penerbit Bulan Bintang. 
E-ISSN: 2808-5361 http://e-journal.fkmumj.ac.id/
Proceeding The First Muhammadiyah InternasionalPublic Health and Medicine Conference

Dariyo, A. (2004) Psikologi Perkembangan Remaja. Bogor: Ghalia Indonesia.

Hadi, S. (2017) 'PEMERIKSAAN KEABSAHAN DATA PENELITIAN KUALITATIF PADA SKRIPSI'.

M, E., Setiadi and Kolip, U. (2013) Pengantar Sosiologi; Pemahaman Fakta dan Gejala Permasalahan Sosial: Teori, Aplikasi dan Permasalahannya. Jakarta.

Monks, F. J. and Knoers, A. M. P. (2006) Psikologi Perkembangan. Yogyakarta: Gajah Mada University.

Mulyono, B. (1993) Mengatasi Kenakalan Remaja. Yogyakarta: Yayasan Andi.

Naresawari, A. D. et al. (2020) 'Analisis pengguna rokok di masa pandemi COVID-19 di Kecamatan Nogosari', Prosiding HUBISINTEK, 1, pp. 72-76.

Salsabil, A. A., Santoso, M. B. and Zainudiin, M. (2020) 'Penanganan Kebiasaan Merokok Di Masa Pandemi Covid-19', Focus : Jurnal Pekerjaan Sosial, 3(2), pp. 131-139. Available at: http://journal.unpad.ac.id/focus/article/view/28458.

Sarwono, S. W. (2012) Psikologi Remaja. Jakarta: PT Raja Grafindo Persada.

Soekanto, S. (2004) Sosiologi Keluarga Tentang Ikhwal Keluarga, Remaja dan Anak. Jakarta: Rineka Cipta. 
Volume I Tahun 2021

November 2021
E-ISSN: 2808-5361

http://e-journal.fkmumj.ac.id/
Proceeding The First Muhammadiyah InternasionalPublic Health and Medicine Conference 